\title{
Aerobic Gram Positive Bacillus
}

National Cancer Institute

\section{Source}

National Cancer Institute. Aerobic Gram Positive Bacillus. NCI Thesaurus. Code C86118.

Any rod shaped bacteria with an oxygen based metabolism and has a peptidoglycan rich cell wall that stains dark purple with the Gram staining technique. 